Published in the Journal of Bahá'í Studies Vol. 2, number 3 (1990)

(C) Association for Bahá’í Studies 1990

\title{
Some Reflections on the Different Meanings of the Word Báb Amelia L. Danesh
}

\begin{abstract}
The Arabic word báb means “door” or "gate.” For Bahá'ís, the word báb is intimately associated with the religious persona of Sayyid "Ali-Muhammad. For Muslims and Islamicists, however, this word has several other meanings. This difference in understanding has resulted in different interpretations of events and figures in Bábí and Bahá'í history by scholars and others approaching the religions from an Islamic perspective. This essay examines the word báb in relation to Islamic architecture, Twelver Shiism, the claims of Sayyid 'Ali-Muhammad, and the status of Mullá Husayn-i-Bushrú'í. It concludes by suggesting that the word báb provides an example of how the Bábí and Bahá'í religions have endowed well-known words and phrases with new meanings.
\end{abstract}

\section{Résumé}

Le mot arabe báb signifie "porte” ou "portail.” Pour les bahá'ís, le mot báb s’associe de près au personnage religieux de Sayyid "Ali-Muhammad. Cependant, ce mot revêt plusieurs autres significations pour les musulmans et les islamistes. Cette différence de compréhension a donné lieu à différentes interprétations des événements et des personnages de l'histoire bábíe et bahá'í par des érudits et d'autres qui adoptent l'approche islamique dans l'étude des religions. Cet essai examine le mot báb par rapport à l'architecture islamique, au Shi'isme du douzième Imam. aux revendications de Sayyid 'Ali-Muhammad et au statut de Mullá Husayn-i-Bushrú'í. En guise de conclusion, l'auteur suggère que le mot báb donne un example de la manière dont les religions bábíe et bahá'í ont doté d'un sens nouveau des mots et des expressions bien connus.

\section{Resumen}

La palabra árabe báb significa puerta o entrada. Para los Bahá'ís, la palabra báb está intimamente asociada con el personaje religioso de Sayyid 'Ali-Muhammad. Para musulmanes e islamicistas, sin embargo, esta palabra tiene otros significados. Esta diferencia de comprensión ha dado lugar a interpretaciones distintas, tanto a los acontecimientos como a las figuras de la historia bábí y bahá'í por parte de los eruditos y demás que se acercan alas religiones desde una perspectiva islámica. Esta disertación analisa la palabra báb relativo a la arquitectura islámica, el Chiismo Docenario, los alegatos de Sayyid 'Ali-Muhammad, y la condicion de Mullá Husayn-i-Bushrú'í. Concluye por sugerir que la palabra báb da un ejemplo de cómo las religiones bábí y bahá'í han dotado de nuevos significados a palabras y frases bien conocidas.

s the Bahá'í Faith has emerged from obscurity, both the Faith and its predecessor, the Bábí religion, have come Aunder increasing scrutiny from the academic world, especially from Islamicists. Accompanying this new recognition from the scholarly world has come an increasingly popular notion that the Bahá'í Faith is a sort of islam manqué. ${ }^{1}$ One of the most obvious examples of viewing the Bábí and Bahá'í religions through the prism of Islamic scholarship relates to the perception of the claims of Sayyid 'Ali-Muhammad (the Báb), This article seeks to examine some of the meanings of the word báb to demonstrate how the Islamic background of the Bahá'í Faith has colored the way the religion is perceived in academic circles.

In Arabic, the word báb (plural abwáb) means “door” or "gate.” For students of the Bábí and Bahá'í religions, the word báb is primarily, and perhaps even solely, associated with the historical figure of Sayyid "Ali-Muhammad.

1. See for instance M. Ruthven, "Beyond the Islamic State,” a review of W. S. Hatcher and J.D. Martin, The Bahá'í Faith: The Emerging Global Religion, in Times Literary Supplement, 25 October 1985. Here, the reviewer writes: "They [Hatcher and Martin] take for granted the Bahai view that Bahaism is now a full fledged religion independent of Islam. Yet the central Bahai doctrines - the Oneness of God, the unity of humankind, the absence of original sin, the creation of a Good Society as a prerequisite for spiritual development - are essentially Islamic. The Bahai methods for achieving the Good Society by creating an embryo world government with an international language may have a nineteenth-century Utopian flavour about it; but it is surely no more than an adaptation to modern conditions of the original Islamic project of creating a universal pax Islamica under a universal Caliphate.” For a response to such criticisms, see M. Afnán and W.S. Hatcher, “The Bahá'í Faith and its Critics,” unpublished paper, 68pp. 
To Shí'í Muslims and students of Islam, however, báb has different meanings. The understanding of the multivalency of this word is a prerequisite to appreciate the first episodes of Bábí history, the milieu within which Sayyid 'Ali-Muhammad made his claim to the title of the Báb, and the subsequent interpretations of this claim. In this essay, the word báb and its implications are studied at four levels.

\section{Báb as a Gateway to Mosques}

The primary and most mundane meaning of the word báb is its use to describe the gateway entrances to mosques, mausoleums, and fortifications (Encyclopedia of Islam 830). The house of Muhammad in Medina has served as the prototype for mosques throughout the Islamic world Most of the features of this first mosque have been perpetuated in masjids even to the present day. Down to the end of the third century A.H. (eighth century A.D.), mosques did not have monumental entrances. All mosques, regardless of size, were entered by plain, rectangular doorways in the enclosure wall. The presence of a monumental entrance or báb, however, was an innovation of the Fatimids. The first mosque built in this fashion dates to 308 A.H. (A.D. 920-21) and was located at the foundation of Mahdiyya on the Gulf of Gabes (Encyclopedia of Islam 830). New types of bábs or portals to mosques have taken on distinctive cultural forms in Syria, Turkey, and Iran.

The word báb also figures in reference to the entrances of fortifications. The earliest gateways of Muslim fortified enclosures were simple "straight-through" entrances. Later, bent entrances called báshura became integral parts of the gateway (Encyclopedia of Islam 830-31). It appears, however, that the gateway leading to perhaps the most famous fortification in Bábí and Bahá'í history, the fort of Shaykh Ahmad-ibn-i-Abí-Tálib-i-Tabarsí, was not elaborate. E.G. Browne describes the simplicity of the fortress of Shaykh Tabarsí and its gateway:

It consists at present of a flat, grassy enclosure surrounded by a hedge, and containing, besides the buildings of the shrine and another building at the gateway...nothing but two or three orange-trees and a few rude graves.... The building at the gateway is two storeys high, is traversed by the passage giving access to the enclosure, and is roofed with tiles. (A Year amongst the Persians 617-18)

While the use of the word báb is commonly associated with the gateway entrances leading to special buildings, this shade of meaning is perhaps the least helpful in understanding the claims of Sayyid 'Ali-Muhammad.

\section{Báb in Twelver Shi'ism}

One meaning of the word báb is specifically related to Shící Islam. The religion of Islam has two major divisions: the Sunní and Shírí branches. They primarily differ in their belief over succession to the Prophet Muhammad. Sunnís believe that upon the death of Muhammad, spiritual leadership was no longer in the hands of any one individual. Therefore, while the Caliphate (the institution which held power over the Islamic Empire after Muhammad) ruled the temporal affairs of Sunní Islam, religious decisions were upheld through ijmá or the "consensus" of the religious scholars (Momen, An Introduction to Shí 'í Islam xix). Sunní scholars arrived at ijtihád (legal decisions) by studying the Sunná (the example of Muhammad's life), the Hadith (traditions), and most important, the text of the Qur'án itself.

The Shí'ah, in contrast, believe that 'Alí, Muhammad's cousin and son-in-law, was the rightful successor to Muhammad (Momen, Shí'í Islam 11). In justification of this claim, Shí 'ís often quote a statement attributed to the prophet Muhammad, and accepted as authentic by both Sunnis and Shí'ís: "I [Muhammad] am the City of Knowledge and 'Alí is its Gate [Báb]" (al-Hákim, al-Mustadrak 299). As an extension of this belief, the Shí'ah hold that the lineal descendants of 'Alí, through his wife Fátima, were in fact the mouthpieces of God on earth. The title given to these descendants of Fátima was Imam. All of them are considered superhumans who were occasionally endowed with the knowledge of the unseen (ílm al-ghayb. MacDermott, Theology 107-9). In contrast to the Sunní Caliphate, the Imamate of the Shí' 'ah was endowed with both political and religious authority.

The most common form of Shiism numbers the Imams as twelve; hence it is referred to as Twelver Shiism. The first Imam was 'Alí, and the last was called Imam Mahdí. The Imam Mahdí is a messianic figure in Shící Islam. Tradition has it that the Imam Mahdí went into hiding or occultation as a young boy to conceal himself from the enemies of Shí 'ism (Momen, Shi' ${ }^{\prime}$ Islam 165). This period of occultation is divided into two stages.

The first stage of hiding lasted forty years. This period is called the "Lesser Occultation.” According to Shí'í orthodoxy, during this time the Imam Mahdí communicated with the Shí'í faithful through four intermediaries, who were called bábs. Later scholarship has emphasized that the deputyship of the Imam was not confined to the four agents in this period, but that the four, in particular, exerted considerable influence in the Imamates of this period. (Sachedina, Islamic Messianism 86-87). The names of these bábs were 'Uthmán al-'Amrí, Abu Ja’far Muhammad. ibn 'Uthmán, Abu’l-Qásim Husayn ibn Rúhan-Nawbakhtí, and Abu’l-Husayn ‘Alí (Momen, Shi'i Islam 162-64). 
These bábs carried messages and tablets from the Hidden Imam to his followers. Each báb designated his own successor. However, the fourth báb did not designate his successor and broke the line of agents who communicated with the Imam. Thus, the period of the "Greater Occultation" took place. This period, which the Shí 'ah believe lasts to the present day, was distinguished by the lack of an agent of the Hidden Imam on earth (Momen, Shi'i Islam 164). The understanding of the word báb in this sense, as an agent to the Hidden Imam, is perhaps the most widespread among the 'ulamá (religious scholars) of the Islamic world.

\section{Báb in Relation to the Claims of Sayyid 'Ali-Muhammad}

This discussion of the Shí'í concept of báb as an agent of the Hidden Imam leads directly to the perception of the claims of Sayyid 'Ali-Muhammad by some Orientalists and later Islamic scholars. In May 1844 a young merchant from Shiraz, who was a descendant of the Prophet (i.e., a sayyid), made a religious claim, the precise nature of which has been a focus of controversy among scholars ever since. According to Bahá'ís, Sayyid 'AliMuhammad declared Himself to be a fulfillment of Shí'í messianism from the time of his declaration to his first follower, Mullá Husayn-i-Bushrú'í (Nabíl, The Dawn Breakers 63; Momen, Shi'i Islam 231). Bahá’í historians suggest that Sayyid 'Ali-Muhammad assumed the title of the Báb to indicate that He was the gateway to another divine teacher. Other observers, notably E.G. Browne, have disagreed with this interpretation. This section will discuss the nature of Sayyid 'Ali-Muhammad's use of the title of the Báb.

Browne was perhaps the first to suggest that Sayyid 'Ali-Muhammad did not claim the station of an independent teacher of God from the outset of his ministry. Rather, he argued that Sayyid "Ali-Muhammad put forth a claim to a station similar to the agents of the Hidden Imam. In an article entitled, "The Bábís of Persia," published in the Journal of the Royal Asiatic Society in 1889 he wrote:

It is interesting to observe that the claim put forward at this period by Mírzá 'Alí Muhammad is that he enjoys a special spiritual communion with the twelfth or absent Imám (Imám-i-Ghá'ib), whose return, as the Imam Mahdí, the Shí'ites are expecting. So far our author does not go much beyond Sheykh Ahmad, who, as we have seen, claimed to receive instructions from the absent Imams. (Quoted in Momen, Selections from the Writings of E.G. Browne 212)

Browne continued with this crucial statement:

It is, I think, in this sense that Mírzá 'Alí-Muhammad at this period assumes the title of "Báb" or "Gate"; he is the gate whereby men must approach the Imám, and the channel whereby the latter reveals to them the true meaning of the Kur'án. (Quoted in Momen, Selections from the Writings of E.G. Browne 212)

Browne then summarized his position:

I do not think that he [Sayyid 'Alí-Muhammad] claimed to be the "Gate of God" (Bábu'lláh), as the Persian historian says in the Násikhu’t-Tawáríkh. (Quoted in Momen, Selections from the Writings of E.G. Browne 212)

More recently, other academics such as Denis MacEoin and Said Amir Arjomand have reiterated Browne's conclusions. For instance, in an article in the journal Religion in 1982, MacEoin wrote:

In its earliest phase [to 1848], Babism grew rapidly...as an expression of extreme Islamic pietism animated by urgent expectations of the return of the Hidden Imam in his messianic persona as the Imam Mahdí, Sayyid 'AliMuhammad being his agent or 'gate' (báb) on earth. In its brief second phase [1848-49]...the Báb...proclaimed himself the promised Mahdí in person. A third phase followed, initiated by the Báb's rapid assumption of the role of an independent prophet or divine 'manifestation' directly empowered by God to open a new religious dispensation after Islam, to reveal new scriptures and to ordain a new legal system. ('The Bábí Concept of Holy War” 93)

In 1984, Arjomand echoed this interpretation:

Mirzá 'Alí Muhammad at first claimed to be the Báb (gate) to the Hidden Imam, but soon relegated the position of the Báb to a disciple [i.e., Mullá Husayn, the Bábu’l-Báb] and claimed mahdihood as the “Qá'im (redresser) 
of the house of Muhammad” ${ }^{2}$

Thus, a Shí'í perspective on the word báb has created an account that fragments the ministry of Sayyid 'AliMuhammad by dividing it into strict sequential periods, each of which is characterized by a certain claim. However, several facts suggest that these interpretations of Sayyid 'Ali-Muhammad's assumption of the title "the Báb" are simplistic.

First, as has been noted elsewhere (Afnán and Hatcher, "Western Islamic Scholarship and Bahá'í Origins”), Sayyid 'Ali-Muhammad established his claim to be the promised Mahdí or Qá'ím in his initial work, the Qayyúmu'l-Asmá, written in 1844. An in-depth analysis of this document in January of 1845 led Sunní and Shí'í clerics to denounce the author (unknown to them) of this work as a heretic because of his claim to divine revelation and the use of the quranic style in his writings (Momen, "The Trial of Mullá 'Alí Bastámí 112-32). If hostile outsiders perceived that the author of this work claimed a station of prophethood, then the claim of Sayyid 'AliMuhammad must have been unequivocally clear to many of his followers (Afnan and Hatcher, "Western" 37-39).

Second, in this same work the Qayyúmu'l-Asmá, Sayyid 'Ali-Muhammad makes a distinction between the two types of bábs. He refers to his forerunners, Shaykh Ahmad-i-Ahsá'í and Siyyid Kázim, as “Gates”:

O ye peoples of the earth! During the time of My absence I sent down the Gates [bábs] unto you. However the believers, except for a handful, obeyed them not. Formerly I sent forth unto you Ahmad and more recently Kázim, but apart from the pure in heart amongst you no one followed them. (The Báb, Selections from the Writings of the Báb 51)

It is revealing to note that in this work, as well as in other Arabic works, Sayyid "Ali-Muhammad refers to Himself as "al Báb," al being the definite article that is translated into English as the. By designating Himself as "al Báb," in contradistinction to his references to other "Gates" (such as Shaykh Ahmad and Siyyid Kázim), Sayyid "Ali-Muhammad established Himself as the Gate of "Him Whom God will make manifest” (man yuzhiruhu alláh) rather than as one of the Gates to the Qá'ím (Universal House of Justice, letter dated 2 July 1987). Hence, Browne’s interpretation (resurrected by scholars today) that Sayyid 'Ali Muhammad did not at first claim a station "much beyond" Shaykh Ahmad, is doubtful.

In a letter written to an individual believer on 30 November 1930, Shoghi Effendi explained the same issue:

By the term Báb, the Báb meant to be the forerunner of the second manifestation rather than, as some have maintained, the gate of the Qá'ím. When he declared Himself to be the Báb, the people understood by the term that he was an intermediary between the absent Qá'ím and His followers, though He never meant to be such a person. All He claimed to be was the Qá'ím Himself and in addition to this station, that of the Bah, namely the gate or forerunner of "Him Whom God will make manifest."

In short, Sayyid 'Ali-Muhammad gave a familiar Arabic word a totally new meaning by his claim. As the Báb, He was both a prophet and a foreteller. This first instance of adding new meanings to well-known words and phrases was to become a hallmark of the Bábí and Bahá'í religions.

\section{The Bábu'l-Báb: A Closer Parallel to “Agents of the Imam”?}

Students of Islam and Orientalists are perhaps inherently inclined to give a Shí'í coloration to the claim of Sayyid 'Ali-Muhammad. Indeed, it is not unlikely that other comparisons of figures in Bábí and Bahá'í history with Islamic figures will take place as the growing body of students of comparative religion begins to establish parallels between the Bábí and Bahá'í religions and Islam. MacEoin, for instance, has already attempted to compare the Bahá'í institution of the Guardianship with the Imamate (MacEoin, "Emerging from Obscurity"). Thus a comparison between the agents of the Hidden Imam (bábs) and Mullá Husayn-i-Bushrú'í (the Bábu'l-Báb) is worthy of consideration.

As was noted above, Mullá Husayn was the first follower of Sayyid 'Ali Muhammad and a leading disciple of the Shaykhí school. The account of his conversation with Sayyid 'Ali-Muhammad is recorded in The DawnBreakers: Nabíl's Narrative. It was at this first private declaration that Mullá Husayn gained the title of the Bábu'lBáb (the gate to the Gate):

2. S. A. Arjomand, The Shadow of God and the Hidden Imam: Religion, Political Order and Societal Change in Shi'ia Iran from the Beginning to 1890, 254. It should be noted that Arjomand cites Browne as one of his major sources in this part of his discussion. 
He then addressed me in these words: "O thou who art the first to believe in Me! Verily I say, I am The Báb, The Gate of God, and thou art The Bábu’l-Báb, the gate of that Gate.” (Nabíl-i-A’zam, The DawnBreakers 63)

On the surface, some similarities exist between Mullá Husayn’s station as Bábu'l-Báb and the agents of the Hidden Imam, the bábs. For instance, both the Bábu'l-Báb and the bábs were explicitly prohibited from disclosing information about their masters. In the case of the agents of the Imam Mahdí they were not allowed to reveal the whereabouts of the Hidden Imam. In: the case of the Bábu'l-Báb, it was the identity of Sayyid 'Ali-Muhammad as the Qa'im that was concealed.

Eighteen souls must, in the beginning, spontaneously and of their own accord, accept Me and recognize the truth of My Revelation. Unwarned and uninvited, each of these must seek independently to find Me....It is incumbent upon you [Mullá Husayn] not to divulge, either to your companions or to any other soul, that which you have seen and heard. (Nabíl-i-A’zam, The Dawn-Breakers 63)

Just as the bábs did not divulge the whereabouts of the Imam Mahdí for some seventy years (a human lifetime) before the "Greater Occultation,” the Bábu’l-Báb refrained from revealing the identity of Sayyid 'Ali-Muhammad for some time as well; Mullá Husayn was joined by his brother and nephew in his new-found Faith after forty days (Shoghi Effendi, God Passes By 7; The Dawn Breakers xvii). In a sense, both the bábs and the Bábu’l-Báb were the links between their masters and the outside world.

However, Mullá Husayn has a far more important spiritual station in the Bahá'í teachings than the bábs have according to Shí'í orthodoxy. In the Kitáb-i-Íqán, Bahá’u’lláh wrote about Mullá Husayn:

...a number of illumined divines, of men of consummate learning, of doctors of mature wisdom, have attained unto His [i.e., Sayyid 'Ali-Muhammad's] Court, drunk the cup of His divine Presence, and been invested with the honour of His most excellent favour....

Among them was Mullá Husayn, who became the recipient of the effulgent glory of the Sun of divine Revelation. But for him, God would not have been established upon the seat of His mercy, nor ascended the throne of eternal glory. (222-23)

Similarly, in God Passes By, Shoghi Effendi refers to the Bábu’l-Báb in these terms:

Mulla Husayn, the first Letter of the Living, surnamed the Bábu'l-Báb (the Gate of the Gate); designated as the "Primal Mirror;" on whom eulogies, prayers and visiting Tablets of a number equivalent to thrice the volume of the Qur'án had been lavished by the pen of the Báb; referred to in these eulogies as “beloved of My heart;" the dust of whose grave, that same Pen had declared, was so potent as to cheer the sorrowful and heal the sick; whom "the creatures, raised in the beginning and in the end" of the Bábí Dispensation, envy, and will continue to envy till the "Day of Judgment .... " (50)

Thus, while there may seem to be some functional parallels between the Bábu'l-Báb of the Bábí religion and the bábs of Twelver Shi'ism, there is no comparison between them in terms of doctrinal importance.

\section{Conclusion}

As used in the Bábí and Bahá'í religions, the word báb has come to take on new meanings and connotations that differ from Shí'í Islam. While comparisons between the Bahá'í Faith and Islam are useful to draw conclusions about the universality of the religious experience, in many cases, such as meanings of the title of báb, these comparisons and contrasts should be drawn especially carefully. Nevertheless, there is a growing tendency of some Islamicists ${ }^{3}$ to see the Bahá'í religion as what it ought to be rather than what it is. This is perhaps to be expected for a religion that is just beginning to emerge from obscurity.

3. Mangol Bayat also seems to have this view of the Bahá'í Faith. See M. Bayat, Mysticism and Dissent: Socio-religious Thought in Qajar Iran 91. 


\section{Works Cited}

Afnán, M., and W.S. Hatcher. "The Bahá'í Faith and its Critics.” Unpublished paper, 68 pp.

—. ”Western Islamic Scholarship and Bahá’í Origins,” Religion 15 (1985): 29-51.

al-Hakim, al Mustadrak. 2:299.

Arjomand, S.A. The Shadow of God and the Hidden Imam: Religion, Political Order, and Societal Change in Shi' 'ia Iran from the Beginning to 1890. Chicago: University of Chicago Press, 1984.

Báb, The. Selections from the Writings of the Báb. Comp. Research Department Trans. Habib Taherzadeh. Haifa: Bahá'í World Centre, 1976.

Bahá’u’lláh, Kitáb-i-Íqán. Trans. Shoghi Effendi. Wilmette, Ill.: Bahá’í Publishing Trust, 1950.

Bayat, Mangol. Mysticism and Dissent: Socio-religious Thought in Qajar Iran. Syracuse: Syracuse University Press, 1982.

Browne, E. G. A Year amongst the Persians. 3d ed. London: Adam \& Charles Black, 1950.

Encyclopedia of Islam (New Edition). Vol. 1. London: Leiden, 1960.

Hatcher, W.S., and Martin, J.D. The Bahá'í Faith: The Emerging Global Religion. San Francisco: Harper \& Row, 1985.

MacDermott, M.J. Theology of al-Shaikh aI-Mufíd. Recherches Nouvelle Série: A; Persian Studies No.9. Beirut: Dar-al-Maschreq Éditeurs, 1978.

MacEoin, D. “The Bábí Concept of Holy War,” Religion 12 (1982): 93.

—_. "Emerging from Obscurity: Recent Developments in Bahá’ísm,” Religion Today, January, 1986.

Momen, M. An Introduction to Shi 'i Islam. New Haven: Yale University Press, 1985.

—. "The Trial of Mullá 'Alí Bastámi: A Combined Sunní-Shi'i Fatwá against the Báb,” Iran, 1982. ed., Selections from the Writings of E. G. Browne on the Bábí and Bahá'í Religions. Oxford: George Ronald, 1987.

Nabíl-i-A'zam. The Dawn-Breakers: Nabíl's Narrative of the Early Days of the Bahá'í Revelation. Trans. Shoghi Effendi. Wilmette, Ill.: Bahá'í Publishing Trust, 1974.

Sachedina, A.A. Islamic Messianism: The Idea of the Mahdí in Twelver Shi 'ism Albany, N.Y.: State University of New York Press, 1981.

Shoghi Effendi, God Passes By. Wilmette, Ill.: Bahá’í Publishing Trust, 1974.

Universal House of Justice, letter dated 2 July 1987 to an individual believer on use of the term Báb. 